Article

\title{
The European Union and State Building in the Western Balkans
}

Andrew J. Taylor

Department of Politics, University of Sheffield, Elmfield, Northumberland Road, Sheffield S10 2TU, UK;

E-Mail: a.j.taylor@sheffield.ac.uk; Tel.: +44 1142221689; Fax: +44 1142221717

\section{How to Cite this Article}

Taylor, A. J. (2013). The European Union and State Building in the Western Balkans. Politics and Governance, 1(2), 183-195.

\section{Acknowledgement}

This Article was published by Librello, Politics and Governance's former publisher.

\author{
About the Journal \\ Politics and Governance is an innovative new offering to the world of online publishing in the Political Sciences. An internationally \\ peer-reviewed open access journal, Politics and Governance publishes significant, cutting-edge and multidisciplinary research \\ drawn from all areas of Political Science. \\ www.cogitatiopress.com/politicsandgovernance \\ Editors-in-Chief \\ Professor Andrej J. Zwitter, Faculty of Law, University of Groningen, The Netherlands \\ Professor Amelia Hadfield, Department of Psychology, Politics and Sociology, Canterbury Christ Church University, UK \\ Managing Editor \\ Mr. António Vieira, Politics and Governance, Cogitatio Press, Portugal
}




\title{
The European Union and State Building in the Western Balkans
}

\author{
Andrew J. Taylor \\ Department of Politics, University of Sheffield, Elmfield, Northumberland Road, Sheffield S10 2TU, UK; \\ E-Mail: a.j.taylor@sheffield.ac.uk; Tel.: +44 1142221689; Fax: +44 1142221717
}

Submitted: 15 April 2013 | In revised form: 17 September 2013 | Accepted: 14 October 2013 |

Published: 7 November 2013

\begin{abstract}
This paper examines the feasibility of network governance in the context of the EU's expansion in the Western Balkans. The EU is formally committed to promoting network governance but the realities of enlargement require the creation of effective states, in other words of the primacy of hierarchy over network. Networks are created in enlargement and reflect the complexities of public policy but these networks do not represent, as yet, a significant shift of power away from the state. Despite a normative preference for network governance, the political reality of enlargement is that the EU seeks the creation of effective hierarchy.
\end{abstract}

Keywords: European Union; governance; state-building; Western Balkans

\section{Introduction}

Zielonka [1] argues EU governance is flawed because it is dominated by a statist paradigm. The EU's response to complexity and heterogeneity is to become even more state-like $[2,3]$ but the EU's complexity ('a polycentric system of government, multiple overlapping jurisdictions, striking cultural and economic heterogeneity, fuzzy borders, and divided sovereignty' [1], p. vii) makes this unrealisable. Zielonka concludes that the EU should explicitly develop 'neo-medieval governance' which would look something like network governance. So, on the one hand, the EU appears suited to network governance, (to which it is normatively committed), but enlargement pulls in the opposite direction, towards hierarchical governance.

The trend in the study of governance is to declare the victory of networks over hierarchy. This paper does not deny the significance of networks, rather it challenges the propositions that networks are, first, a new form of governance; second, that networks have supplanted hierarchy; and third, networks diffuse power, reducing the centrality of the state. My argument is that networks (multi-level and horizontal) are an inevitable response to complexity, describe political reality, and do not necessarily signal a shift in the distribution of power. Enlargement, I argue, requires high capacity and capability states which points to an even more complex, differentiated (and divided) EU in which hierarchy dominates.

We have a puzzle: enlargement is hierarchical but the EU has an expectation of network governance [4,5]. What does the coexistence of hierarchy and networks mean for the distribution of power in a polity? Enlargement and policy complexity explain why networks form, do they explain their operation? If enlargement is dominated by hierarchy and if, from a path dependency perspective, initial conditions are critical, does 
the emphasis on hierarchy undermine the EU's preference for a more diffuse, responsive, and accountable power structure? In enlargement, hierarchy is functionally superior to networks and necessary because of the national government's centrality in satisfying EU conditionality; government therefore mandates actions and defines the nature of network interaction, which takes place 'under the shadow of hierarchical authority' ([6], pp. 40-41).

The first section addresses the governance revolution and the supposed victory of networks and this is explored further in the second section with reference to EU enlargement. It argues that so great is the gap between the Western Balkan states and the EU it can only be bridged by hierarchy. The third section argues that hierarchy is inevitably the primary focus of enlargement, paradoxically creating both networks and concentrating power.

\section{The Governance Revolution}

The rise of governance was predicated on the assumption that from the 1980s there was decline in governing capacity ([7], p. 2, for example). Governing, or government, refers to purposeful actions to guide, steer, control or manage using hierarchy and the capacity and capability to adopt and enforce decisions ([8], p. 551). Governance is the non-hierarchical coordination of state-society interaction based on the involvement of non-state actors in making and implementing policy in which non-state actors enjoy considerable autonomy. The characteristic institution produced by the (apparent) shift from government to governance is the network, a concomitant of which is the 'rollingback' of the state $[9,10]$. 'Network' here refers to a cluster of public and private actors in a policy sector that persists over time and whose members' make and implement policy. The explosion of work on multilevel and horizontal interaction has made 'network' into a common descriptor of the EU and well suited to understanding the EU's consensual-bargaining policy process ([11], pp. 3-13; [12], pp. 27-49; [13], pp. 53-54).

The growth of social complexity facilitated resistance to central guidance, and networks developed to improve policy and limit the potential for resistance ([14], p. 20). Governance (and network) theory holds that 'no single actor, public or private, has all knowledge and information required to solve complex, dynamic and diversified problems' ([7], p. 3). Policy and politics are, however, always driven by public-private interaction (when was a single actor ever totally dominant?) but network theory stresses not interaction but interdependence of such a degree that government is reduced to the status of just another actor because of its reliance on non-governmental actors. Governability problems were stimulated by, and their solution required, public and private actor engagement in such complex ways that interaction becomes interdependence, but the hypothesised shift from interaction to interdependence, assumes societal actors possessed and exploited their resources and strategic location to neutralise government. Therefore 'Reciprocity and bargaining rather than hierarchy describes the way the service delivery system functions' ([15], p. 380).

As a concept governance has several flaws, notably it 'can be observed and experienced, but nobody can in fact do it' ([8], p. 550, original emphasis). Confusion is increased by linking 'governance' and 'network' to a degree that they become synonymous and the literature avoids a substantive discussion of power, focussing on power 'to' not power 'over'. Governance embraces a vast field of interaction between non-state actors and government, becoming a near catch-all category. The problem is that 'control deficits' and 'implementation gaps' always exist and 'the only leakproof system...is where the instigator and executor are one person' ([15], p. 362). Control deficits and implementation gaps create and sustain space for hierarchy ([8], p. 551) so 'empirically, only hybrid forms may be found since one mode of governance always entails elements of other modes of governance. Otherwise, effective steering and co-ordination would not be possible' ([16], p. 3).

Hierarchy and network co-exist and the task of government is to facilitate and manage socio-political interaction in different policy sectors (which may require the government's withdrawal from, or intervention in, a policy sector). Governments need knowledge to understand problems, identify solutions, allocate and define responsibilities, organise implementation and apply sanctions. Interaction is inevitable but need not challenge power relations through the production of interdependence. Governance as a concept is vulnerable to 'grandiose semantic overstretch' and can justify both the extension and the substitution of the state ([8], pp. 553, 556).

Networks possess resources that government values but government has resources needed by networks, resources that give governments important advantages. Whether interaction becomes interdependence depends on, first, the nature of resources; and second, the degree to which supply is monopolised. Interaction becomes interdependence when critical resources are controlled by a few actors; interdependence is unlikely when there are many suppliers or if the supply (and quality of the resource) is poor. Hierarchy's key advantages are: authoritative and legitimate decisionmaking, the coordination of complexity, and the ability to create networks.

Coordination needs networks of separate but interacting organisations to amplify collective capabilities and improve problem-solving. The central issue, therefore, is 'how does the central government coordinate the fragmented system so that its policies are achieved' ([15], p. 364; see also [17], pp. 94-108)? Government cannot rely on self-regulation or self-organisation; neither, as liberal democracies, can they routinely employ coercion, which leaves interaction (especially 
in the hyper-compound EU polity) usually in classic Weberian-bureaucratic ways. Thus, 'central governments are, in formal terms, the principal agents for major allocations to an operating ideology since, in the last resort, they can legislate for the necessary change' ([15], p. 372, emphasis added). The EU combines, as do national governments, 'old' (hierarchy) and 'new' (network) governance but the intergovernmental nature of the EU (and the complexity of national politics) means that the Commission (and national governments) 'steer' change and create, and exploit networks. Enlargement creates policy networks where none hitherto existed, or changes radically existing networks. Societal actors can be viewed as impediments or as assets but the Commission encourages the formation of networks ([18]). Before proceeding we must distinguish this argument from external governance. External governance is distinguished from enlargement by its lack of a membership perspective, which reduces dramatically the incentives for a country to bear the costs of adaptation (for example, [19]). This paper focuses on a particular process: the creation of the member state: 'a distinctive kind of state where national power is exercised in concert with others' ([20], p. 4).

How issues are resolved-hierarchy, markets, network-can vary over time and by policy sector but in all cases the centre dominates. The result is that 'government and governance... are actually much more intertwined than is implied by some governance theorists' ([21], p. 484). This means that interaction need not become interdependence. The Commission and enlargement states have a special interest in effectiveness so governments-and therefore hierarchy-define network dynamics. 'Not to put too fine a point on it', Sharpe concluded, 'government is not just another organization' ([15], p. 381).

\section{The EU Governance Puzzle and Enlargement}

Under the Treaty on the European Union any European (not defined) country may apply for membership if it respects the democratic values of the EU and is committed to promoting them. The 1993 Copenhagen European Council defined the accession criteria (the Copenhagen criteria) thus: countries must have stable institutions guaranteeing democracy, the rule of law, human rights and respect for and protection of minorities; a functioning market economy and the capacity to cope with competition and market forces in the EU; and the ability to take on and implement the obligations of membership, including adherence to the aims of political, economic and monetary union. The Copenhagen Criteria point clearly to a particular state form. Accession is determined by the candidate's adoption, implementation and enforcement of all current EU rules (the acquis) which are divided into thirty-five policy chapters, whose content is not negotiable. The Commission monitors, gives advice and guidance, as well as assuring current members that conditionality is being applied. This process is clearly directed at creating a particular state but also ensuring its effectiveness. Effectiveness is essentially a state's ability to formulate and implement policies, in cooperation with society, in pursuit of collective goals. Does the EU engage in state-building?

The EU does not have a single, coherent statebuilding strategy in the Western Balkans but does have a range of policies and delivery mechanisms implemented across a variety of countries which, when taken in the round, seek the creation of functioning liberal democracies capable of joining the EU and undertaking the obligations of membership. There is now a fairly extensive literature examining the EU's role in the Western Balkans and the impact of conditionality and the nature of state building [22-26]. In their different ways these sources explore the transformative effect of the conditionality inherent in enlargement and a realistic prospect of membership, and their consequences for state-building. However, the reliance on conditionality as a state-building mechanism has been deemed 'largely ineffective' because of 'the lack of commitment of political elites to $\mathrm{EU}$ integration and the persistence of status issues on the policy agenda' ([27], p. 1783). This article, in contrast to Bieber's, is concerned not so much with the causes of any ineffectiveness but with the broader issue of the scale of the misfit between EU conceptions of the state and what exists in the WB (Western Balkans). The EU emphasised creating effective hierarchy by exploiting the opportunities offered by conditionality. The EU's problem in the WB is the problem of stateness but state-building is complex for the EU, which raises questions about the effectiveness of conditionality in stimulating change.

Bieber focuses on the minimalist state defined as 'state structures which fall short of the set of functions most states are widely expected to carry out [but] might be able to endure' ([27], p. 1784), and focusses on Bosnia and Herzegovina, Kosovo and the Union of Serbia and Montenegro (which no long exists) whilst ignoring the region's non-minimal states. The minimalist state does not capture the variety of state forms or stages of development covered by enlargement in the region, what this paper refers to as the WB7 (Croatia, Montenegro, Macedonia, Serbia, Albania, Kosovo, Bosnia and Herzegovina). All, both minimal and non-minimal states, are deeply engaged with the EU through the enlargement process. EU state building, as defined by Bieber, is security driven and originally concerned with conflict prevention but it merges into institution building, which assumes the existence of a state already capable of delivering minimal functions. Institution building is, therefore, part of state building but not identical with it as the latter concentrates on core institutions and sovereignty and is broader and less tangible than the former. State and institution building, as Bieber ([27], p. 1791) concedes, are located 
on a continuum and contained by an overarching process, member state building, involving the creation of not just effective states but states able to sustain the obligations of membership. Central to both state and institution building is conditionality but this leaves open specifics and national variation. Statements such as the Copenhagen Criteria do not resolve the problem of effective transposition or preference change, which limits the EU's transformative power, the secondary (or indirect) effects involving accommodating (or creating) institutions to European ways and triggers extensive social learning. Engagement with the EU involves extending the state's scope and increasing institutional capacity but this does not inevitably result in greater decentralization; indeed, as we have seen, the EU's preference is for decentralised governance but this is a normative preference and far more important for enlargement is effectiveness, which means hierarchy. In other words, in enlargement is about creating hierarchy.

The EU's objective is the creation of effective states so how can we measure variation in effectiveness? Variation is estimated using two measures; data drawn the World Bank Governance Indicators and the Freedom House measure of political rights. Government Effectiveness (GE), one of the six measures comprising the Governance Indicators, estimates the 'effectiveness gap'. It captures 'perceptions of the quality of public services, the quality of the civil service and the degree of its independence from political pressures, the quality of policy formulation and implementation, and the credibility of the government's commitment to such policies' ([28], p. 4). I identify two main groups: the Enlargement 12 (Cyprus, Estonia, Malta, Slovenia, Czech Republic, Slovak Republic, Latvia, Hungary, Poland, Lithuania, Bulgaria (2007), Romania (2007)) and the seven Western Balkan states and entities seeking membership or, in Croatia's case, achieving it (Table 1 and Table 2). The first WGI (Worldwide Governance Indicators) data is for 1996 and this is the base-line for the (then) EU15 (Austria, Belgium, Denmark, Finland, France, Germany, Greece, Ireland, Italy, Luxembourg, Netherlands, Portugal, Spain, Sweden, United Kingdom) and represents the 'target' for enlargement states, ratings for 2011 provide comparison. The measure is expressed in units of a standard normal distribution, with a mean of zero, a standard deviation of one, with a range between -2.5 to 2.5 ; higher values corresponding to better governance. The EEA (European Economic Area) is omitted as already approximating the EU model, and Turkey, whose Islamic culture poses a set of different issues.

This narrowing effectiveness gap indicates some convergence between the EU15 and the Enlargement 12 but the picture becomes more complicated when the WB7 are included. It is difficult to identify a baseline date for the WB7 (1996 is unrealistic as all were in the throes of Yugoslavia's break-up or transition); the signing of a Stabilisation and Association Agreement (SAA) with the EU marking the start of a formal interaction is a good starting point but these came into operation at different times (2 in 2001, 1 in 2006, 3 in 2008) so 2004 is a convenient mid-point.

This indicates no significant convergence (the WB7/EU15 gap closed because of decline in the latter, not improvement in the former) and considerable variation in effectiveness. The 2011 data for the Enlargement 12 and WB7 suggests two groups: states (excluding Bulgaria and Romania but including Croatia) with an average GE of 0.66 (Croatia's is 0.60) and those (including Bulgaria and Romania but excluding Croatia) with an average GE of 0.51, Bulgaria's and Romania's scores are 0.49 and 0.48 respectively. The GE for the EU15 is 1.46. A further level of complexity is the variation within the EU 15: in 2011 Finland scored 2.25, Italy is the lowest at 0.45 (Greece, invariably presented as the EU's basket-case, is 0.48).

The extension of democracy and political rights is, as we have seen, a prerequisite for enlargement, so how do the three groups of compare (Table 3 and Table 4)? Taking the EU 15 as the benchmark, the Enlargement 12 data shows change over time and this group contains variations: Romania (1998, 2004, 2007 and 2011) with an index of 2.0, Slovakia (1998) 2.0, Latvia (2011) 2.0, and Bulgaria (1998, 2011) with 2.0, all are rated 'free'. The WB 7 are different (Table 4).

Croatia shows considerable improvement after 1998 and is on a par with the EU 15 and Serbia is following a similar trajectory but the remainder are defined as 'partly free', which suggests democratisation has some way to go. Enlargement requires the combined development of democracy and hierarchy; variation is inevitable and due to history, the nature of the enlargement process, and the response of national elites to the pressures of adaptation.

Table 1. The effectiveness gap: The EU 15 and the Enlargement 12.

\begin{tabular}{lccc}
\hline & $\mathbf{1 9 9 6}$ & $\mathbf{2 0 0 4 / 0 7}$ & $\mathbf{2 0 1 1}$ \\
\hline EU15* & 1.64 & 1.69 & 1.46 \\
Enlargement 12** & 0.57 & 0.64 & 0.63 \\
Difference & 1.07 & 1.05 & 0.83 \\
\hline
\end{tabular}

Notes: ${ }^{*} \mathrm{EU} 15=$ Austria, Belgium, Denmark, Finland, France, Germany, Greece, Ireland, Italy, Luxembourg, Netherlands, Portugal, Spain, Sweden, United Kingdom; **Enlargement $12=$ Cyprus, Estonia, Malta, Slovenia, Czech Republic, Slovak Republic, Latvia, Hungary, Poland, Lithuania, Bulgaria (2007), Romania (2007).

Table 2. The effectiveness gap: The EU 15, the Enlargement 12 and the WB7.

\begin{tabular}{lcc}
\hline & $\mathbf{2 0 0 4}$ & $\mathbf{2 0 1 1}$ \\
\hline EU15 & 1.69 & 1.46 \\
Enlargement 12 & 0.64 & 0.63 \\
WB7* & 0.52 & 0.52 \\
\hline
\end{tabular}

Note: ${ }^{*} W B 7=$ Croatia, Montenegro, Macedonia, Serbia, Albania, Kosovo, Bosnia and Herzegovina. 
Table 3. The Freedom House Index (Political Rights): EU 15, Enlargement 12 and WB7.

\begin{tabular}{lcclc}
\hline & $\mathbf{1 9 9 6}$ & $\mathbf{2 0 0 4 / 0 7}$ & $\mathbf{2 0 1 1}$ & Rating \\
\hline EU 15 & 1.0 & 1.0 & 1.0 & Free \\
Enlarge- & 1.25 & 1.08 & 1.20 & Free \\
ment 12 & 1.0 & 2.9 & 3.0 & $\begin{array}{c}\text { Partly } \\
\text { Free }\end{array}$ \\
WB 7 & 4.0 & 2
\end{tabular}

Table 4. The Freedom House Index (Political Rights): The WB 7.

\begin{tabular}{lllll}
\hline & $\mathbf{1 9 9 8}$ & $\mathbf{2 0 0 4}$ & $\mathbf{2 0 0 7}$ & $\mathbf{2 0 1 1}$ \\
\hline Albania & 4.0 & 3.0 & 3.0 & 4.0 \\
Bosnia & 5.0 & 4.0 & 3.0 & 4.0 \\
Croatia & 4.0 & 2.0 & 2.0 & 1.0 \\
Kosovo & -- & -- & -- & 5.0 \\
Macedonia & 3.0 & 3.0 & 3.0 & 3.0 \\
Montenegro & -- & -- & 3.0 & 3.0 \\
Serbia & -- & -- & 3.0 & 2.0 \\
\hline
\end{tabular}

Key: 1.0-2.5 free: broad scope for open political competition, a climate of respect for civil liberties, significant independent civil life, and independent media; 3.0-5.5 partly free: some restrictions on political rights and civil liberties, often in a context of corruption, weak rule of law, ethnic strife, or civil wars; 5.5-7.0 not free: basic political rights are absent and basic civil liberties are widely and systematically denied. From 2003 partly free = 3.0-5.5; not free 5.5-7.0. Source: [29].

Treib, Bähr and Falkner ([16], pp. 3-4, 5-10, 15) identify three dimensions of governance: politics (decision making is divided between government and private actors), polity (institutions different from markets and hierarchies), and policy (a mode of political steering). Treib et al. then combine legal instruments (legally binding statements versus soft law) and implementation (rigid versus flexible), which they describe as 'the most critical' features, to develop a four-fold typology of modes of governance. The most relevant mode is framework regulation (binding legal instruments combined with flexible implementation) which comes closest to capturing enlargement as a centrally (European) mandated process in which national governments are responsible for implementation. As a mode of governance framework regulation indicates the primacy of hierarchy coupled with networks (see also [30]).

A core EU objective in enlargement is to reduce variation between states by policy transfer and norm diffusion. Enlargement places states under massive downwards pressure to adapt, creating the capacity needed to satisfy the obligations of membership. This is hierarchy, but the EU (theoretically) favours network governance. Enlargement is driven by inter- and trans-governmental negotiations to ensure compliance; enlargement is dominated by hierarchy to achieve effectiveness. 'Network' permeates the EU's conception of 'good' governance (policy making and implementation to open to publics, non-state organisations and civil society) utilising five principles-openness, participation, accountability, effectiveness and coherence
([31], p. 18). The principles underpinning enlargement are unchanged and constitute the bedrock of enlargement since Europe's post-Cold War 'reunification'. These principles are exactly that: principles. They offer no detailed guidance and therefore, the task of the Commission, other European institutions and, of course, the Member States ([32], pp. 258-259). The devil is in the detail.

Commission officials insist the Western Balkan states have a credible membership perspective (dating from the Zagreb Summit in 2000) but, with the exception of Croatia, accession remains a distant prospect. The accession process became longer, more intensive and intrusive extending into 'post-accession conditionality' ([33]). Enlargement poses complex problems for EU institutions and imposes great domestic strains; the EU, in line with the provisions governing enlargement, employs conditionality, monitoring, and rule transfer to push polities towards 'the European model' of market, liberaldemocratic states. The EU and Commission stress this is not a coercive process; states are not obliged to undertake these reforms but if they are not undertaken to the satisfaction of the Commission membership will not be forthcoming. The progressive tightening of the policing of the enlargement process was the result of the Commission's assessment of its experience in Central and Eastern Europe and a changing political and economic environment. The Western Balkan countries pose problems that make the 'big bang' enlargement of 2004 look straightforward. The general attitude of enlargement countries remains, irrespective of specific complaints and grumbling about the length of the process, one of 'better in than out'. Given the broad consensus that the EU is 'the only game in town', one can understand why a high priority is accorded membership. Although the costs of adaptation are high and the process long, and requires surrendering (or pooling) sovereignty, membership is perceived to be in the national interest.

To navigate enlargement, countries must possess sufficient personnel, knowledge, expertise, to implement and coordinate complex tasks in state building and integration. EU preferences and the bulk of governance theory sees the involvement (and neutralisation?) of societal groups as simple prudence as well as improving effectiveness and compliance; improving a state's ability to govern through (Mann's [34] infrastructural power) rather than over society. This implies an enabling state, a state 'steering not rowing' and interacting extensively with non-state actors to exchange information, accumulate expertise, enhance trust and improve problem-solving ([35], pp. 76-77). However, accession states lack capacities and capabilities that, when combined with conditionality, increase state autonomy and shift the emphasis to hierarchy. The default response is to assert hierarchy and centralise power. Networks develop because of policy complexity and downwards pressure from both the EU and national governments; so the presence of networks per se indicates neither network governance nor a diffusion of power. Engagement with the EU empowers state actors; the state is not as hollow as we think. 


\section{The Inevitability of Hierarchy}

The EU seldom refers directly to state building, preferring synonyms (for example, 'a well-functioning and stable public administration', a 'neutral civil service', a 'politically independent judiciary') to describe activities that constitute, in effect, state-building. Basic statements on enlargement, notably the Copenhagen Criteria (CEC 1993 [35]) and subsequent amplifications (for instance CEC 1997 [36] and CEC 1999 [37]) offer mainly principles. Nonetheless, enlargement requires a country 'bring its institutions, management strategy and administrative and judicial systems up to Union standards and with a view to implementing the acquis...' ([38], p. 7). Despite lacking an institutional model the capacity and normative elements inherent in enlargement stimulated the European Administrative System (EAS) that does influence directly the contours of the state ([39], pp. 506-531).

A basic principle is that national administration is the responsibility of national government but the EU 'does influence how Member States govern themselves' ([40], p. 120). The EU shies away from any explicit reference to state-building for four reasons: first, it is dealing with sovereign states; second, it lacks resources and personnel; third, change is best designed and implemented by those with the fullest knowledge and understanding of local conditions; and fourth, local ownership is essential to ensure change is embedded and sustained. Over time, and despite national variation, however, states have converged on what constitutes 'good' governance. This consensus embraced 'the rule of law, principles of reliability, predictability, accountability and transparency, but also technical and managerial competence, organisational capacity and citizens' participation' ([41], p. 5). These constitute a preferred regime-the market, plural liberal democracy-and the extent to which these principles were accepted and embedded by a state seeking membership testified to a determination to create the state capabilities and capacities and quality of democracy that characterise a member state.

Within the overall expectation that inputs and outputs are generated in a particular way ('obligation de résultat') states, whether members or aspirant, 'are free to set up their public administration as they please, but it must operate in such a way as to ensure that community tasks are effectively and properly fulfilled to achieve policy outcomes which are set by the Union' ([40], p. 121). The interconnectedness of the effectiveness and democratic criteria 'meant establishing new constitutional provisions transferring power to elected representatives, laws protecting freedom of opinion and expression, the establishment of a multiparty system and the possibility for the electorate to replace those in power' $([40]$, p. 122). This is statebuilding and a limited range of variations are acceptable.

To avoid having to engage directly with statebuilding, which is politically sensitive with imperial overtones, the EU split state-building into two separ- ate processes: democratisation and capacity building, a distinction it strove to maintain in the 2004 and 2007 enlargements and thereafter. Democratisation was a national and popularly driven process supported, but not directed, by the EU ([42], p. 3) but capacity building required a more overt EU role because 'it is necessary to focus as much on the candidates' capacity to implement and enforce the acquis...' ([43], p. 5). Combined these produced a particular type of state which transited from central planning and political authoritarianism to markets and pluralism 'while at the same time gearing themselves up to the sophisticated machinery of European integration' ([42], p. 5).

As assessment of PHARE (Poland and Hungary: Assistance for Restructuring their Economies) found there was no evidence that the Commission had used PHARE to push institutional change even though what existed was 'ill-suited to manage the transition to, and needs of democratic market economies, or the accession process'. PHARE was extended to eight of the 102004 enlargement states as well as Romania and Bulgaria. It was replaced by ISPA (Instrument for Structural Policies for Pre-Accession) and IPA (Instrument for Pre-Accession Assistance). Institutions proved resilient and resistant to change, they remained highly politicised and often ineffective [44]. CEE states undertook a double-transition, WB states faced a triple transition-marketisation, democratisation and nationbuilding - a far more significant challenge for them and the EU. Here the relationship between statebuilding and European integration was far closer than in CEE. 'For the first time', Rupnik writes, 'in its history [the EU was] directly involved in assisting the creation of its future member states', encouraging the creation of 'Brussels-oriented constitutions' ([45], p. 34). In 2005 the Commission lauded the EU's transformative power in CEE but admitted 'the Western Balkans is a particular challenge...Enlargement policy needs to demonstrate its power of transformation in a region where states are weak and societies are divided' ([46], p. 2). Enlargement 'requires the creation of a legally constituted state, acting under the rule of law and with the elimination of arbitrary use of public power. It therefore presupposes a thorough transformation of the system of governance' ([40], p. 122). In the WB 'basic issues of state building, good governance, administrative and judicial reform, rule of law including the fight against corruption and organised crime, reconciliation, socio-economic development, are key reform priorities for the Western Balkans' ([47], p. 22).

This can be illustrated by the resources expended on institution building (Table 5) that buttress democratic transition and marketisation by strengthening democratic institutions, administrative and judicial capacity, and civil society. They show the significance attached to institution building by the EU as well as problems with capacity and capability that indicate serious shortcomings with hierarchy. 
Table 5. Instrument for pre-accession: Component I Transition assistance and institution building (percentage of total IPA expenditure by country/year).

\begin{tabular}{lrrrrrrrr}
\hline & $\mathbf{2 0 0 7}$ & $\mathbf{2 0 0 8}$ & $\mathbf{2 0 0 9}$ & $\mathbf{2 0 1 0}$ & $\mathbf{2 0 1 1}$ & $\mathbf{2 0 1 2}$ & $\mathbf{2 0 1 3}$ & Average \\
\hline Albania & 89.0 & 88.3 & 87.9 & 89.4 & 89.3 & 90.0 & 88.7 & 88.9 \\
Bosnia & 93.5 & 93.3 & 94.1 & 95.5 & 95.5 & 95.1 & 95.0 & 82.3 \\
Croatia & 35.1 & 31.0 & 30.1 & 25.6 & 25.4 & 25.6 & 18.6 & 27.3 \\
Kosovo & 100.0 & 100.0 & 100.0 & 98.2 & 97.3 & 97.3 & 95.7 & 98.3 \\
Macedonia & 71.1 & 58.5 & 48.1 & 40.2 & 30.0 & 28.2 & 23.8 & 42.8 \\
Montenegro & 87.2 & 86.1 & 84.9 & 88.9 & 87.3 & 46.7 & 14.4 & 70.7 \\
Serbia & 95.6 & 93.9 & 93.6 & 94.0 & 94.4 & 94.3 & 94.3 & 94.2 \\
\hline Average & 81.6 & 78.7 & 76.9 & 75.9 & 62.0 & 68.1 & 61.5 & \\
\hline
\end{tabular}

Source: derived from data in [48].

Enlargement entails extensive state-building in polities with a history of centralisation and weak civil societies ([49], pp. 116-142), that, together with the Commission's emphasis on creating an effective state, prioritises hierarchy over network. The state is not being by-passed or transcended but changed and the change 'increases the intervention capacity of the state by bringing non-state actors into the making and implementation of public policy' ([8], p. 555). However, this interaction need not increase interdependence. Treib, Bähr and Falkner, for example, argue 'there is no mode of governance that includes either only public or only private actors. It can only be stated that a certain type of actor is predominant' ([16], p. 9, emphasis added). Combining structure (who does what), process (how it operates) and outcomes (what is produced) networks are an essential and universal component of governance and all governance is obviously and necessarily multilevel and complex and in the EU is dominated by governments. In enlargement the Commission is an authoritative allocator of value. The EU is governed through networks but not by networks and governments act as gatekeepers and authoritative decision-makers. Hierarchy is dominant in enlargement and reinforced by conditionality. Hierarchy precedes network; the problem is how to demonstrate this.

Engagement with the EU has stimulated extensive rule adoption and institution building ([50]; see also [51]) that can plausibly be described as state-building. The study on which this paper draws explores the development of policy networks as a result of engagement with the EU and the frequency and intensity of interaction in these networks using Social Network Analysis (SNA) employing UCINET/Netdraw (see [52]) to penetrate politics, polity and policy ([53], pp. 2629). A combination of semi-structured interviews and a structured questionnaire allowed us to explore how policy networks emerged and developed and how their members interacted; the analysis combines 'thick description' and systematic analysis across policies and countries. The study covered Greece (a longstanding EU member), Slovenia (a relatively recent member), Croatia (then on the verge of accession), and Macedonia (still a long way from accession) and examined three policy areas (cohesion, borders and migration, and environmental policy) utilising data from 120 respondents. This produced twelve SNA maps; this paper omits Greece, leaving 62 interviews and nine SNA maps, far too many to be discussed in depth here. All were recognisably networks, albeit with varying architecture. However, this paper uses insights drawn from the data to comment on the nature of networks and their relationship to hierarchy.

The networks are composed of organisations connected to each other in a relationship intended to deliver policy in a fashion satisfactory to the EU. The paper assumes that the specifics of each policy-based network can be used to identify general patterns of resource exchange and dependence. SNA helps us understand which actors play a critical role in determining how problems are resolved, relationships managed and to what extent (and which) goals are achieved. Network theory is often used descriptively or metaphorically $[54,55])$; in The European Union and South East Europe [53] we were interested not just in the actors but their relationships. The network is influenced by, and influences, actors' behaviour and norms, and whilst SNA takes actors seriously it is primarily concerned with relationships, not actor attributes. Combining SNA and interview data enables power and influence to be explored systematically, locating networks in their environment, an environment structured by the EU and national governments. This produced an interesting result: the EU may not be a highly visible participant in a network although actors perceive it to be an influential, or even determining, influence on a network. SNA identifies networks but what is the role of hierarchy?

First, the EU requires the transposition of the acquis and legislation and the creation of appropriate institutions. Both the legislation and the institutions flow directly from EU requirements and were put in place as a result of action by national governments, an unequivocal example of hierarchy. Second, the centrality of hierarchy was reinforced by the dominance in each network of a central ministry in both horizontal and vertical policy relationships. This is reinforced by shortages of capacities and capabilities at different tiers of government but which tend to be concentrated at the centre thereby increasing the 
centre's pull. Finally, NGO and citizen participation is normatively good but, lacking resources and expertise, they find their role is often restricted to providing information and legitimacy for central actors and their preferences. The cumulative effect is to reinforce hierarchy, which contrasts with the EU's emphasis on network governance. However, engagement with the EU has created networks and citizen and NGO participation was widely perceived as valuable for good policy and as an end in itself, a response flowing directly from engagement with the EU.

The acquis must be transposed, so there is a highlevel of downwards adjustment pressure, but many interviewees regarded the inevitable changes in institutions and norms as intrinsically worthwhile as part of a wider modernisation, as well as necessary to obtain membership. Allowing for sectoral and country differences we found three patterns: first, a 'core' (or 'strategic') group of actors within the networks, central was the responsible sectoral ministry; second, over time network relations became increasingly complex (more members at more levels) and more intense (scale of interaction). This was allied to a belief by actors that 'pluralisation' per se offered the possibility of better policy in terms of content, legitimacy, and implementation. Third, there was no direct connection between pluralisation and power diffusion. The centre remained dominant; interaction did not become interdependence. There is, therefore, a potential for a reduction in the centre's dominance over time but a historical institutionalist perspective as well as the need to bridge the capacity gap between the WB states and the wider EU and achieve membership is unlikely to reduce significantly hierarchy's dominance.

A policy network is an arena of extended and intensive interaction and communication, embodying values so an important aspect of networks is norm transference and behavioural change. Time ([56], p. 259 ) is an important element of the process, creating the opportunity for behavioural and attitude change. This lengthy process is designed to establish an evolutionary trajectory, rather than signalling arrival at a destination. EU governance norms, preferences, and policy, pass through a filter-the national government -which is responsible for transposition and implementation, and the overall effect is to sustain centralised power and hierarchy. We conceptualised this as a 'capacity bargain' whose functional, political and administrative dimensions constitute the cutting-edge of Europeanization. In The European Union and South East Europe we employed the capacity bargain to explore the impact and implications of engagement with the EU in policy networks with varying mixes of resources and actors, but structured by the requirements of EU policy and demands of domestic implementation ([53], pp. 17-21). The capacity bargain is not about 'filling' a state with capacity as if it were an empty vessel; rather the acquis and the 35 chapters pose specific, sectoral issues of institutional creation and adaptation. Capacity bargains, being sectoral, are analogous to policy networks but are focussed on enlargement; they promote 'state-effectiveness' because of EU membership requires the creation of an effective state ([57], pp. 51-70). We found no instances of interviewees rejecting network governance (either on grounds of principle or utility), we did find scepticism about the suitability and feasibility of network governance because of policy complexity, a lack of resources and expertise, competing political loyalties, and the primacy of accession. Early patterns of engagement and resource distribution are difficult to alter; networks are 'hardened' power reflecting a set of relationship and rewards and are resilient, requiring a powerful exogenous shock to stimulate change. Our evidence is that the Commission will trade network for hierarchy thereby reinforcing central power. Engagement with the EU stimulates change in governance (whether this is transformative is a matter of empirical analysis), but towards hierarchy.

The Commission retains maximum flexibility in negotiations although strictly speaking chapter negotiations are not 'negotiations' [58]. The annual Progress Reports' purpose is to stimulate the creation of effective hierarchy and the evolution of capacity and capability. The networks created are new and are a site for socialisation bringing domestic and supranational actors together in repeated dense interactions over time, so opening up the possibility of preference change. EU engagement creates novel domestic policy sectors and institutions influenced by a distinct ethos. Though authoritative the EU does not impose change, it expects domestic actors to interact in new ways reinforced by, for example, Twinning and joint projects. Slowness and vagueness are intrinsic to the learning process that rests on the creation of appropriate hierarchies mobilising and coordinating relevant non-state and societal actors.

Elites (and society) agree their futures lay in the $\mathrm{EU}$; there is a credible membership perspective and adaptive pressures are at work. Compared to CEE, enlargement is now far more individualised and much more closely policed. The power asymmetry inherent in enlargement is de facto coercive (unless an applicant follows EU prescriptions it cannot join) and requires more than strategic adaptation involving the creation and evolution of networks (grounded on the acquis chapters) in which EU derived institutions and norms, interact and link actors in new ways for new purposes [59]. Even when laws were passed implementation could be delayed or even postponed because the administrative structures were insufficient or even lacking. Networks can be, therefore, 'hollow'. General progress can co-exist with sectoral variations, with embedded weaknesses in capacities persisting; though eager to develop network governance transposition via hierarchy took priority. The focus on effectiveness and hierarchy stimulated multileveled-ness but horizontal networks and partnership working remained underdeveloped. Technical knowledge and working 
methods were transferred by EU engagement but shortages of capability and capacity and the load inherent in enlargement placed a premium on developing hierarchy.

Networks can significantly increase the capacity of state actors without increasing the influence of nonstate actors. A huge policy load, high EU expectations and limited capacity dictates societal involvement in policy development and implementation but the state's pivotal role in enlargement limits the influence of non-state actors who, in any case, often lack the resources to play the role allotted by network governance. Cooperation and interaction with non-state actors, whilst inevitable, does not automatically reduce state autonomy and, given enlargement's emphasis on effectiveness, the greater the capacity for hierarchical action, the lower the incentive for engagement with resource constrained non-state actors. The point is that turkeys do not vote for Christmas; governments involve non-state actors to the extent that their involvement enables the former to achieve its objectives, notably EU membership. Hierarchy/ network is not a binary choice because governments seek to preserve their autonomy and enhance their ability to achieve their policy objectives. Network governance is resource intensive and coordination is complex so why move decisively away from hierarchy? A good case can be made for building up central capacity first. The evidence in The European Union and South East Europe [53] showed governments were often suspicious of non-state actors, regarding them as 'watchdogs', as sources of friction, not partners. Similarly, while non-state actors need resources and partners they too value their autonomy and fear capture by the state. Network governance will not, therefore, emerge quickly and certainly not during enlargement.

Though obviously not WB states Bulgaria and Romania shows the limits of the EU's transformative power and offer insights into the EU's likely approach to the Western Balkans. After 2007 Romania and Bulgaria were subject to the Cooperation and Verification Mechanism (CVM) addressing serious shortcomings in justice and home affairs, and corruption. In Bulgaria CVM established six benchmarks (judicial independence, accountability, transparency and efficiency; high-level and public sector corruption; and combating organised crime) on which the Commission was to report regularly [60]. Important legislation was passed but strategic gaps remained and the political will to deliver varied. The Commission identified a lack of direction and uncertain domestic commitment, concluding external pressure remained essential, which raises questions about the irreversibility and sustainability of change. In Romania's case four benchmarks (judicial reform, judicial integrity, high-level, and public sector corruption) were identified [61]. The Commission's quinquennial review was scathing. A lack of progress was combined with events that raised serious concerns about the political elites' commitment to, or even understanding of, the rule of law. Romania, the
Commission argued, was not being asked to achieve standards higher than those in other Member States but to implement what it had already agreed. Implementation problems and the absence of a consistent developmental trajectory raised the possibility of reforms already in place being reversed; hence the need for continued external pressure.

CVM was a response to the shortcomings of the 2004 enlargement. First, there was a perception that the historical significance of 'the return to Europe' could not be permitted to fail, which suggested states had been allowed to join the EU that were not ready and there had been insufficient emphasis on the EU driving domestic change. Second, Bulgaria and Romania testified to the limits of the Commission's transformative power. Third, adaptation was a 'centre-led' process involving passing legislation, drawing up strategy documents, securing funds and spending them, tasks that required the creation and development of central capacity [62]. Change was driven by (and from) the centre and by the need to secure Commission approval to ensure that the polity was set on an evolutionary trajectory ending in membership. So whilst enlargement and the Commission's role are presented as transformative, noteworthy are the limits to this external pressure. Uncertainty over accession, domestic counter-pressures and history reduce the pressure to reform but so would a premature commitment because once a country joins the incentives to reform decline markedly. There is, furthermore, evidence of 'back-sliding' in public sector reform in the 2004 membership states; SIGMA [63] found the process of public administration reform slowed after membership and that in some cases there had been a regression to previous patterns of behaviour.

CVM led the Commission to re-think 'post-accession' conditionality and the dangers of premature accession. CVM is not being applied to Croatia. The Commission prepares six-monthly progress reports covering judiciary, fundamental rights, war crimes, corruption, and shipyard privatisation. The October 2012 report on Croatia identified five areas where increased effort was required together with twelve more specific tasks ([64], p. 17). There was no explicit treaty reference to delaying accession but the European Council is empowered to 'take all appropriate measures' in the event of any adverse report, lifting these measures when its concerns have been addressed satisfactorily. There are three 'safeguard clauses' to deal with any problems encountered with Croatia as an EU member; a general economic safeguard clause (for adjustment difficulties); a specific clause relating to the internal market; and a specific justice and home affairs clause, plus various transitional provisions. The safeguard clauses are precautionary and probationary and allow Member States to impose protective measures or the EU to suspend specific rights up to three years after accession and continue as long as necessary.

Croatia's accession (the most rigorous thus far) 
has, as happened after previous enlargements, stimulated a re-think. Candidate states from now on are subject to the 'European Semester-lite', supplemented by specific interventions but 'the crucial point...is the change in our approach to the Chapters 23 and 24 [that are] a fundamental instrument of the transformation...they touch upon the basic principles on which the EU founded' [65]. Chapters 23 and 24 are 'the acquis of the acquis' and, Füle argued, would permeate negotiations from the start to 'enable us to participate in the full transition to democracy during the whole negotiation process...the goal for the EU is not to tick the box of negotiated chapters...' [65].

The emphasis accorded to justice, organised crime and corruption, security, and fundamental rights shows the change in enlargement's context and the EU's limits. In addition to being fundamental issues these emphasised the centrality of the reform of public administration and the development of an effective, modern, 'European' State. Public administration reform involved institutional reform and transmitting and institutionalising values and norms such as openness, accountability, and transparency. This is apparent in the negotiating framework (June 2012) for Montenegro, which was itself a consequence of the problems of the Bulgaria, Romania, and Croatia accessions and difficulties anticipated with the remaining enlargement states ([66], p. 2).

Acquis implementation could not be achieved without first strengthening capacity and asserting hierarchy. Hence the EU's increasing focus on public administration [67], a synonym for state-building. NGOs often noted a decline in their influence, being actively courted when legislation and strategy were being developed but then being ignored. This was partly a result of a lack of skills but mainly because of the focus on creating an effective state and a feeling that networks could be obstructive ([53], p. 201). Institutions have been created and modified in response to EU requirements; this has stimulated learning and extended involvement in policy-making downwards and outwards and actors believe involvement will influence the evolution of policy networks. This is unlikely to lead to a shift from hierarchy to network, from interaction to interdependence, because the basic pressures are to create hierarchy.

\section{Conclusions}

In an increasingly complex, differentiated and divided EU how is order to be created and maintained? Offe suggests the governance's literature's focus on networks ignores 'questions of power, distribution, and conflict' ([8], p. 558). Effective policy is more likely when made and implemented via hierarchy; governments remain authoritative, if not unfettered, decision makers. The purported shift from hierarchy to network assumes a marked decline in government effectiveness, which can be compensated for by involving societal actors in partnership with government, but this increases complexity, reducing government effectiveness further. This network paradox is complicated in enlargement. National governments are critical because only states can join the EU and national administrations are responsible for putting in place, under Commission monitoring and guidance, the capacities and capabilities needed to sustain the duties and obligations of membership. Whether or not these actions satisfy the EU's requirements is decided by the Commission.

Enlargement and integration are state building, a process whose direction is determined and aided by the EU, reinforced by a national commitment to membership. A national government can be simultaneously 'weak' but 'stronger' than both sub-national governments and non-state actors. In enlargement hierarchy is functionally superior because enlargement is primarily about creating an effective state, and networks enhance state effectiveness.

Network characteristics-multiple actors, resource exchange, and negotiation and bargaining and the associated values of openness, accountability, representativeness, participation-are easily identified. Networks per se do not represent a significant move away from hierarchy. Any mode of governance will be hybrid ([16], p. 11). When networks are created, if the state is the most significant actor, it is likely to remain so diminishing the prospects for network governance. The state is not being rolled-back or hollowed-out. What we see is the state rolling-forward and filling-in. This is reflected, in part, in the focus on Chapter 23 (judiciary, fundamental rights) and Chapter 24 (justice, freedom and security) and why these chapters have become 'the acquis of the acquis'. This points to the enhancement of government which occurred because, first, domestic policy was often underdeveloped and differed markedly from what the EU envisaged; and second, change was unavoidable driven as it was by enlargement. States could not hope to approximate the EU's organisational and normative preferences without first creating the appropriate hierarchies.

Hierarchy is prior to network; satisfying the EU and achieving membership requires, first and foremost, an effective state, and an effective state rests on bureaucratic and administrative competence and a secure (and known) legal framework. This means that network governance cannot be realised during enlargement, nor can it substitute for an effective state. To reiterate: enlargement is not concerned with creating network governance but creating effective hierarchies. The situational logic of enlargement dictates the primacy of hierarchy and that networks are a functional response to enlargement and complexity and not a new form of governance.

\section{Acknowledgments}

The empirical and theoretical issues discussed in this paper are explored further in [53]. My co-authors are not responsible for my analysis or interpretation of the data. 


\section{References}

1. Zielonka J. Europe as Empire. The Nature of the Enlarged European Union. Oxford, UK: Oxford University Press; 2006.

2. Barroso M. Europe as Solution: Facts and Myths. SPEECH/11/1. 3 January 2013. Brussels, Belgium: European Community; 2013.

3. Rehn O. Reforming Europe, beating the crisis. SPEECH/15/12, 11 January 2013. Brussels, Belgium: European Community; 2013.

4. Hix S. The Study of the European Union II: The 'new governance' agenda and its rivals. Journal of European Public Policy. 1998;5(1):38-65.

5. Wincott D. Looking Forward or Harking Back? The Commission and the Reform of Governance in the European Union. Journal of Common Market Studies. 2001;39(5):897-911.

6. Scharpf FW. Games Real Actors Play: Positive and Negative Coordination in Embedded Negotiations. Journal of Theoretical Politics. 1994;6(1):27-53.

7. Kooiman J. Socio-Political Governance: Introduction. In: Kooiman J, editor. Modern Governance. New Government-Society Interactions. London, UK: Sage Publications; 1993.

8. Offe C. Governance: An "Empty Signifier"? Constellations. 2009;16(4):550-562.

9. Ansell C. Network Institutionalism. In: Rhodes RAW, Binder SA, Rockman BA, editors. The Oxford Handbook of Political Institutions. Oxford, UK: Oxford University Press; 2006. pp. 75-89.

10. Enroth H. Policy Network Theory. In: Bevir $M$, editor. The Sage Handbook of Governance. London, UK: Sage Publications; 2011. pp. 19-35.

11. Eising R, Kohler-Koch B. Introduction: Network governance in the European Union. In: Kohler-Koch $B$, Eising $R$, editors. The Transformation of Governance in the European Union. London, UK: Routledge; 1999. pp. 3-12.

12. Kohler-Koch B, Rittberger B. The "Governance Turn" in EU Studies. Journal of Common Market Studies. 2006:44(1):27-49.

13. Börzel TA. Network: Reified Metaphor or Governance Panacea? Public Administration. 2011;89(1):4963.

14. Mayntz R. Governing Failures and the Problem of Governability: Some Comments on a Theoretical Paradigm. In: Kooiman J, editor. Modern Governance. New Government-Society Interactions. London, UK: Sage Publications; 1993. pp. 9-20.

15. Sharpe LJ. Central Coordination and the Policy Network. Political Studies. 1985;33(4):361-381

16. Treib O, Bähr H, Falkner G. Modes of governance: Towards a conceptual clarification. Journal of European Public Policy. 2007;14(1):1-20.

17. Dreschler W. The Re-Emergence of "Weberian" Public Administration after the Fall of New Public Management: The Central and Eastern European Perspective. Haldskultur. 2005;6:94-108.
18. Lenschow A. Environmental Policy: Contending Dynamics of Policy Change. In: Wallace $H$, Pollack $M$, and Young $A$, editors. Policy-Making in the European Union. 6th ed. Oxford, UK: Oxford University Press; 2010. pp. 307-330.

19. Lavenex S, Schimmelfennig F. EU rules beyond borders: theorizing external governance in European politics. Journal of European Public Policy. 2006;16(6): 791-812.

20. Bickerton C. European Integration. From NationStates to Member States. Oxford, UK: Oxford University Press; 2013.

21. Jordan A, Würzel RKW, Zito A. The Rise of "New" Policy Instruments in Comparative Perspective: Has Governance Eclipsed Governance? Political Studies. 2005;53 (4):477-496.

22. Cohen JJ, Lampe JR. Embracing Democracy in the Western Balkans. From Post-Conflict Struggles toward European Integration. Baltimore, MD, USA: Johns Hopkins University Press; 2011.

23. Trauner F. The Europeanisation of the Western Balkans: EU justice and home affairs in Croatia and Macedonia. Manchester, UK: Manchester University Press; 2011.

24. Fagan A. Europe's Balkan Dilemma. Path to Civil Society or State-Building? London, UK: I.B. Tauris; 2012.

25. Noutcheva G. European Foreign Policy and the Challenges of Balkan Accession Conditionality, Legitimacy and Compliance. London, UK: UACES/Routledge; 2012.

26. Elbasani $A$, editor. European Integration and Transformation in the Western Balkans. London, UK: Routledge; 2013.

27. Bieber F. Building Impossible States? StateBuilding Strategies and EU Membership in the Western Balkans. Europe-Asia Studies. 2011;63(10):1783-1802.

28. Kaufmann D, Kraay A, Mastruzzi M. The Worldwide Governance Indicators. Methodology and Analytical Issues. Policy Research Working Paper 5430. Washington, DC, USA: The World Bank; 2010.

29. Freedom House. The Freedom House Index of Political Rights. Available from: www.freedomhouse.org (accessed on 29 July 2013).

30. Nicolaides P. Microfoundations of Policy Implementation. Towards European Best Practice. London, UK: Routledge; 2012.

31. Commission of the European Communities. European Governance. A White Paper. $\operatorname{COM}(2001) 428$ final, 25 July 2011. Brussels, Belgium: EU Commission; 2011.

32. Avery G. Uses of time in the EU's enlargement process. Journal of European Public Policy. 2007;16(2): 256-269.

33. Gateva E. Post-Accession Conditionality. Support Instrument or Continuous Pressure? Working Paper No. 18. The Transformative Power of Europe. Berlin, Germany: Freie Universität; 2010.

34. Mann M. The Autonomous Power of the State: Its Origins, Mechanisms and Results. Archives Européenes 
de Sociologie. 1984;25(2):185-213.

35. Council of the European Union. European Council Conclusions, Copenhagen 21-22 June 1993. Available from: http://www.europarl.europa.eu/enlargement/ec/p df/cop_en.pdf (accessed on 10 June 2012).

36. Council of the European Union. European Council Conclusions, Luxembourg, 12-13 December 1997. Available from: http://www.consilium.europa.eu/uedocs/cms _data/docs/pressdata/en/ec/032a0008.htm (accessed on 10 June 2012).

37. Council of the European Union. European Council Conclusions, Helsinki, 10-11 December 1999. Available from: http://www.consilium.europa.eu/uedocs/cms_dat a/docs/pressdata/en/ec/ACFA4C.htm (accessed on 15 August 2012).

38. Commission of the European Communities. Guide to the Main Administrative Structures Required for Implementing the Acquis. Informal Working Document for Guidance Only (updated May). Brussels, Belgium: DG Enlargement; 2005.

39. Olsen JP. Towards a European Administrative Space? Journal of European Public Policy. 2003;10(4): 506-531.

40. Fournier J. Governance and European Integration -Reliable Public Administration. SIGMA Paper no. 23. Paris, France: OECD; 1998.

41. OECD. European Principles for Public Administration. SIGMA Paper no. 27. Paris, France: OECD; 1999.

42. Commission of the European Communities. Enlargement Strategy Paper; 2000. Available from: http:// ec.europa.eu/enlargement/archives/key_documents/rep orts_2000_en.htm (accessed on 20 September 2012).

43. Commission of the European Communities. Making a Success of enlargement. Strategy Paper; 2001. Available from: http://ec.europa.eu/enlargement/archive s/pdf/key_documents/2001/strategy_en.pdf (accessed on 23 September 2012).

44. OMAS Consortium. Assessment of the EU Phare Programmes. Multi-Country Thematic Report on Public Administration Reform; 2001. Available from: http:// ec.europa.eu/enlargement/pdf/financial_assistance/phar e/interim_s_zz_pad_01003_fv_en.pdf (accessed on 23 October 2012).

45. Rupnik J. EU Enlargement in the Balkans: A Comparison with Central Europe. In: Accession of the Western Balkans to the EU: Evaluating a Process. Paris, France: Sciences Po; 2010.

46. Commission of the European Communities. Enlargement Strategy Paper COM(2005) 561 final Brussels, 9 November 2005. Brussels, Belgium: EU Commission; 2005.

47. Commission of the European Communities. Western Balkans: Enhancing the European Perspective COM (2008) 127 final, 5 March 2008. Brussels, Belgium: EU Commission; 2008.

48. Commission of the European Union. Enlargement. Instrument for Pre-accession Assistance. Available from: http://ec.europa.eu/enlargement/instruments/overview/i ndex_en.htm (accessed on 2 September 2013).
49. Mazower M. The Balkans. From the End of Byzantium to the Present Day. London, UK: Phoenix Press; 2000.

50. Renner S, Trauner F. Creeping EU-membership in Southeast Europe: The Dynamics of EU Rule Transfer to the Western Balkans. Journal of European Integration. 2009;31(4):449-465.

51. Trauner F. Deconstructing the EU's Routes of Influence in justice and Home Affairs in the Western Balkans. Journal of European Integration. 2009;31(1): 65-82.

52. UCINET Software. Available from: www.analytic tech.com/ucinet (accessed on 6 June 2009).

53. Taylor AJ, Geddes A, Lees C. The European Union and South East Europe. The Dynamics and Europeanization and Multilevel Governance. London, UK: UACES/ Routledge; 2012.

54. Wellman B. Structural Analysis: From Method to Metaphor to Theory and Substance. In: Wellman B, Berkowitz SD, editors. Social Structures: A Network Approach. Cambridge, UK: Cambridge University Press; 1988. pp. 19-61.

55. Dowding KH. Model or Metaphor? A Critical Review of the Policy Network Approach. Political Studies. 1995;43(3):136-158.

56. Avery G. Uses of time in the EU's enlargement process. Journal of European Public Policy. 2009;16(2): 256-269.

57. Geddes A, Taylor AJ. How Capacity Bargains Strengthen States: Migration and Border Security in South-East Europe. West European Politics. 2013;36(1): $51-70$.

58. Confidential Interview. European Commission, 9 April 2009.

59. Taylor AJ. The Europeanization of Environmental Policy: Institutional Creation and Evolution in Croatia and Macedonia. Paper presented at the workshop "Environmental Governance in Southeast Europe and the Western Balkans: Reassessing the Transformative Power of Europe", 8-9 February 2013, Berlin, Germany. Berlin, Germany: Freie Universität; 2013.

60. Commission of the European Communities. On Progress in Bulgaria under the Cooperation and Verification Mechanism. COM(2012) 411 final, 18 July 2012. Brussels, Belgium: EU Commission; 2012.

61. Commission of the European Communities. On Progress in Romania under the Cooperation and Verification Mechanism. COM(2012) 410 final, 18 July 2012. Brussels, Belgium: EU Commission; 2012.

62. Confidential Interview. European Commission, 31 March 2009.

63. Meyer-Sahling J-H. Sustainability of Civil Service Reforms in Central and Eastern Europe Five Years after EU Accession. SIGMA Paper no. 44. Paris, France: OECD; 2009.

64. Commission of the European Communities. Main Findings of the Comprehensive Monitoring Report on Croatia's state of preparedness for EU Membership. COM(2012) 601 final, 10 October 2012. Brussels, Belgi- 
um: EU Commission; 2012.

65. Füle S. Enlargement brings 'positive' news in times of crisis'. EurActiv, 13 August 2012; 2012. Available from: www.euractiv.com/enlargement (accessed on 15 October 2012).

66. Commission of the European Communities. Enlargement Strategy and Main Challenges 2012-2013.
$\operatorname{COM}(2012) 600$ final, 10 October 2012. Brussels, Belgium: EU Commission; 2012.

67. Elbasani A. EU Administrative Conditionality and Domestic Downloading. The Limits of Europeanization in Challenging Contexts. The Transformative Power of Europe Working Paper No. 2. Berlin, Germany: Freie Universität; 2009. 